\title{
Nature-based tourism as an \\ alternative for sustainable development in the Altas Montañas de Veracruz region, Mexico
}

\author{
Pérez-Sato, Juan A.; Real-Luna, Natalia; Alcántara-Salinas, Graciela; Rivera-Hernández, Jaime E.; \\ Muñoz-Márquez-Trujillo, Rafael A.*; Zárate-Rodríguez, Araís; Zalazar-Marcial, Edgardo; \\ Sánchez-Páez, Ricardo; Castillo-González, Luis A.
}

Colegio de Postgraduados Campus Córdoba. Carretera Federal Córdoba-Veracruz km 348, Manuel León, Amatlán de los Reyes, Veracruz, México. C. P. 94946.

*Autor para correspondencia: arturomecolpos.mx

\begin{abstract}
Objective: Determine the current state of nature-based tourism in the High Mountains Region of Veracruz, Mexico, by the analysis of participatory workshop results with most of the municipal tourism managers of the region.

Design/methodology/approach: A participatory workshop took place, the "1st. Nature-based Tourism Forum of the Altas Montañas de Veracruz Region", for which an evaluation instrument was elaborated. The questionnaire, called "Technical Sheet for the Diagnosis and Inventory of Touristic Initiatives", was filled by the participants. During this participatory workshop, the region was divided into five subregions and participants worked in separate tables by subregion.

Results: 106 consolidated projects were registered, 38 in process and 130 elements with tourism potential were identified; 53 problems that affect tourism in the region were also identified. A total of 123 people participated: 61 of them representing 32 municipalities, 16 were from seven municipalities, 12 represented five institutions and 34 people were organizers.

Limitations of the study/implications: The greatest limitation faced by this project was the participation of all municipal authorities throughout the whole region.

Findings/conclusions: Out of the 57 municipalities in the region 32 attended (more than 56\%). The number of consolidated projects (106) is high, considering $44 \%$ of the municipalities were not present, which highlights that the majority are of the community and private management. However, most of the projects in process are organized by municipalities, which indicates their interest in tourism. Regard the elements with touristic potential in the region (natural and historical sites and traditions), the number registered was high (130). This is a consequence of the great biocultural wealth in the area, which can be developed and conserved through ecotourism.
\end{abstract}

Keywords: Forum; Ecotourism; Rural tourism; Biocultural wealth.

\section{INTRODUCTION}

Nature tourism refers to those trips that aim to carry out recreational activities in

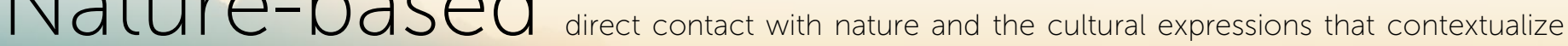
them, especially with an attitude and commitment to know, respect, enjoy and participate in the conservation of natural and cultural resources. These trips are grouped according to the interest of the tourist in three main modalities: 
"Ecotourism", "Adventure Tourism" and "Rural Tourism" (SECTUR, 2017). Thus, in recent years, nature-based tourism has come to occupy an important place in Mexico, being used as a sustainable development option for rural and indigenous groups in the country (López-Ojeda et al., 2019). The implementation of tourism in rural areas not only in Mexico but throughout Latin America has promoted high expectations as a promoter of social, economic and ecological change, considering this type of tourism as the solution to the problems of the rural environment (Kieffer, 2018). However, although this tourism represents a sustainable alternative for natural and cultural resource usage, it depends on how it is planned and developed so that it becomes a viable and real option.

The Altas Montañas de Veracruz region, Mexico, is one of the 10 regions in which the state is divided (INAFED, 2010) and is made up of 57 municipalities, including two of the largest cities in the state: Córdoba and Orizaba and their respective conurbation areas. The largest altitudinal gradient in Mexico is found in this region, which ranges from approximately 70 to 5,636 meters above sea level (Rivera-Hernández et al., 2018) in a strip of around $100 \mathrm{~km}$ wide on average, which gives it remarkable characteristics. The objective of this research was to develop an inventory of the tourism projects of the region and to carry out an exchange of experiences, to have a scenario of the state in which they are located in the area to form a tourism network in the region. the region was divided into five subregions: 1) Huatusco-Tlaltetela, 2) Pico de Orizaba, 3) AcultzingoOrizaba, 4) Zongolica-Tezonapa and 5) Córdoba-Center (Figure 2). Each worktable systematized the technical inventory sheets, their analysis, and doubts clarification. For those municipalities that had not previously sent the required data, the information was obtained from these tables.

\section{Tourism projects classification}

The projects in the technical sheets were codified, classified, and defined as follows:

\section{Community management. It} refers to the management of touristic projects through the local population, who control and manage their common welfare,

\section{MATERIALS AND METHODS}

In order to achieve the current state of nature-based tourism at the Altas Montañas de Veracruz region, Mexico, we carried out a participatory method consisted of a workshop where the municipal authorities of the 57 municipalities were invited to attend. This workshop was organized through the Master's Program in Landscape and Rural Tourism of the Colegio de Postgraduados Campus Córdoba; the workshop called: "1st. Regional Forum of Nature Tourism of the Altas Montañas de Veracruz region", to assess first-hand, the tourism initiatives that the municipal governments are carrying out and supporting.

To publicize the event, a poster was printed with relevant information about this workshop (Figure 1) and an official letter was sent to the authorities of each of the 57 municipalities in the region, specifying the information about the event and its objectives. An evaluation instrument in the form of a questionnaire, called "Technical Sheet for Inventory and Diagnosis of Tourism Initiatives" was also prepared and distributed amongst the participants, so that it would be filled out before the reunion to reduce the filling time during the event (Table 1). The poster and the information of the event were published on social media one month in advance so that doubts of potential participants were addressed, both via social networks and email. The workshop was held on April 18, 2018, from 9:00 a.m. to 2:30 p.m. To develop a structured work, work tables were organized, where

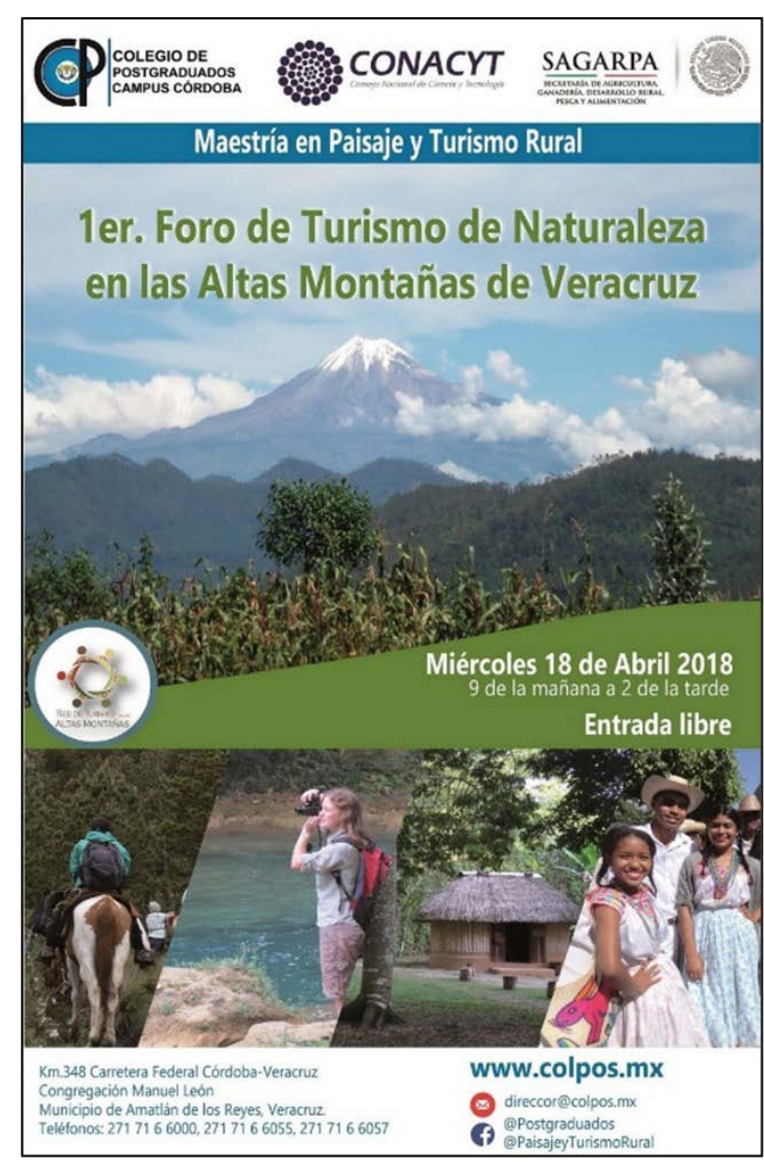

Figure 1. Poster of the 1st. Regional Forum on Nature Tourism in the Altas Montañas de Veracruz region. 
Table 1. Technical inventory sheet and diagnosis of tourism initiatives at the Altas Montañas de Veracruz region, Mexico.

List and mention the tourist projects that exist in your municipality

What localities are included in your municipality? (If you like, you can draw a picture of the municipality to locate them geographically)

What kind of tourism servies do yo offer? (cabins, zip line, trails, tours, swimming pools, archaeological site, festivities, etc.) Please describe

Who is the responsible of the tourism services mentioned? By the communities, individuals, or the municipal government?

In case your municipality does not have a tourism project. Could you mention some places that have the potential to undertake tourism projects? Could you mention why they have potential?

Would your municipality like to be joined in a tourism network seeking inter community support and benefit? If you say yes, could you add your main reasons?

Your municipality has problems or any problem that avoid the establishment or the prosperity of tourism project? What would these problems be?

Your municipality would be interested in training for the development of tourism projects? Why?

This space is free if you would like to add something missing of your municipality, any aspect regarding tourism issues is welcome

based on the organizational figures of their community structure (Del Barco-Quiroga, 2010).

Private management. It refers to management by people who do not belong to any type of community organizational figure, call it a community or "ejido". It can be a single person or a group of organized people.

Municipality management. Projects which management comes from the municipal authorities in charge of tourism development.

Rural tourism. Tourism whose purpose is the interaction of visitors with a receiving rural community, in activities of their typical social, cultural, and productive expressions (SECTUR, 2004).

Ecotourism. It refers to tourism whose main characteristic is been responsible for the visited natural and cultural environment, visitors who respect the environment stand out (SECTUR, 2004).
Adventure tourism. In Mexico, this tourism is defined as that where trips are made to carry out recreational activities related to challenging conditions by air, land, or water while interacting with nature (SECTUR, 2004).

Historical/religious tourism. It relates to an interest in the cultural, social, or historical relevance at the visited site (García Muñoz-Aparicio et al., 2017).

Gastronomic tourism. It is the type of tourism where gastronomy is the main reason to travel to a certain place (OMT, 2017).

Both historical/religious tourism and gastronomic tourism are included in this study, since, in the assessed region, these are mainly developing in rural areas, thus forming part of rural tourism.

Others. Includes other types of tourism not considered in those specified above.

\section{Problems and limitations}

The technical sheet also consulted about the problems with nature-based tourism. The classification of the problems was shared with the workshop participants so that they all maintained the same criteria. The problems were classified as follows:

Environmental. These are those problems that affect tourism that relate to the natural environment.

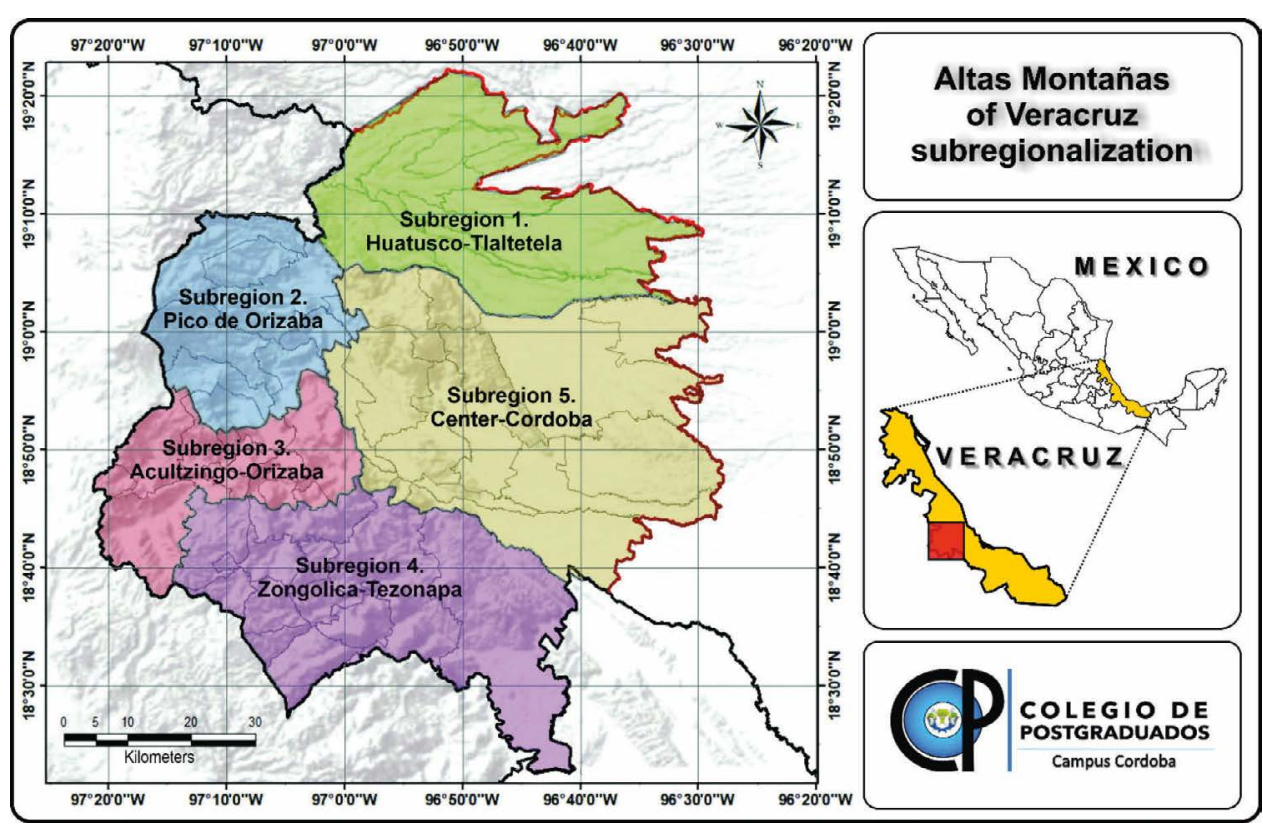

Figure 2. Subregionalization map of the Altas Montañas de Veracruz region, Mexico. 
Social. Those problems where the impact on tourism comes from the social environment that surrounds it.

Economical. Those effects on tourism where the main element relates to a lack of economic resources.

Technical. Those effects whose main element is the lack of technical training on tourism.

For the analysis of the obtained data, descriptive statistics were used, graphs and tables to better illustrate the results obtained were developed.

\section{RESULTS AND DISCUSSION}

The workshop was attended by 123 people, 61 were from 32 municipal councils, 16 individuals from seven municipalities and 12 representatives from five institutions: Faculty of Biological and Agricultural Sciences, Universidad Veracruzana, Servus, AC, Colegio de Postgraduados Campus Veracruz, Universidad Tecnológica del Centro de Veracruz and Direction of the Cofre de Perote National Park, National Commission of Protected Natural Areas (CONANP). The Colegio de Postgraduados Campus Córdoba participated with 34 organizers (Table 2).

\section{Consolidated projects}

In the region, 106 consolidated projects were registered. A consolidated project refers to a touristic product made up of tangible and intangible elements and attractive resources, which already have services, equipment and infrastructure, have planned leisure or recreational activities and has an identifiable image in the market (SECTUR, 2003). Most of these projects are managed by individuals and communities and are of ecotourism type (Table 3; Figure 3).

\section{Projects in process}

In total, 38 projects were registered as in process in the region. In this case, those developed by municipalities stand out, the majority of which are ecotourism in nature (Table 4, Figure 4).

\section{Elements with touristic potential}

A total of 130 elements with tourist potential were registered for the region. This group of elements refers to those sites (waterfalls, rivers, lagoons, caves, mountains, flora and fauna, etc.), traditions (patron saint festivities, ethnic festivities, "jaripeos", festivals, etc.) or historical remains ("ex-haciendas", archaeological remains, etc.), which currently have no touristic use, but

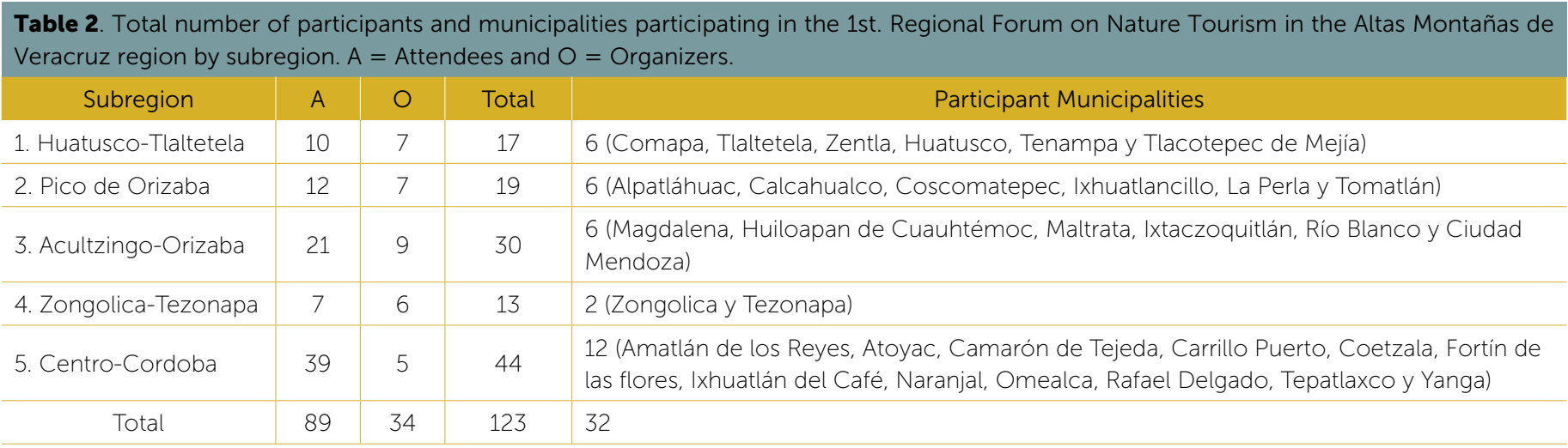

\begin{tabular}{|c|c|c|c|c|c|c|c|c|c|c|}
\hline \multirow{2}{*}{ Subregion } & \multirow{2}{*}{$\begin{array}{c}\text { Consolidated } \\
\text { projects }\end{array}$} & \multicolumn{3}{|c|}{ Type of management } & \multicolumn{6}{|c|}{ Type of tourism } \\
\hline & & C & $\mathrm{P}$ & $M$ & $\mathrm{R}$ & $E$ & $A$ & $\mathrm{H} / \mathrm{R}$ & G & Other \\
\hline 1. Huatusco-Tlaltetela & 20 & 10 & 5 & 5 & 0 & 6 & 2 & 7 & 2 & 3 \\
\hline 2. Pico de Orizaba & 32 & 22 & 6 & 4 & 1 & 11 & 0 & 15 & 1 & 4 \\
\hline 4. Zongolica-Tezonapa & 13 & 5 & 4 & 4 & 0 & 9 & 1 & 2 & 1 & 0 \\
\hline 5. Centro-Cordoba & 18 & 1 & 16 & 1 & 0 & 11 & 3 & 3 & 1 & 0 \\
\hline Totals & 106 & 43 & 43 & 20 & 1 & 55 & 11 & 27 & 5 & 7 \\
\hline
\end{tabular}


Type of management of consolidated projects

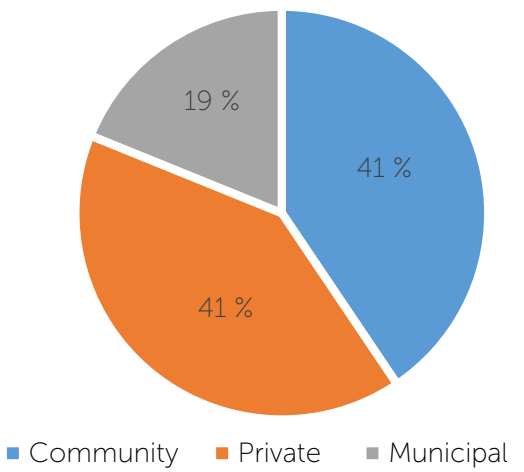

Type of tourism of the consolidated projects

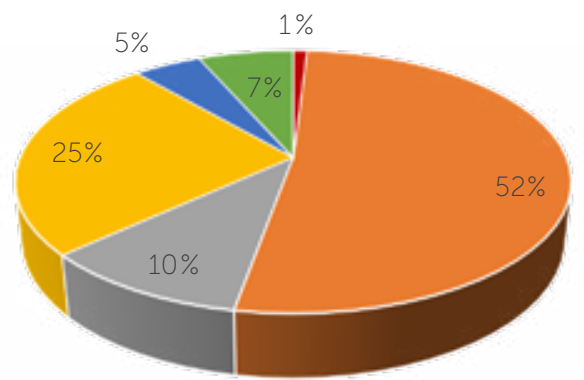

- Rural

- Ecotourism

- Adventure

- Historical/religious - Gastronomy

- Others

Figure 3. Percentages of management types and types of tourism in consolidated projects in the Altas Montañas de Veracruz region, Mexico.
Type of tourism of the projets in progress

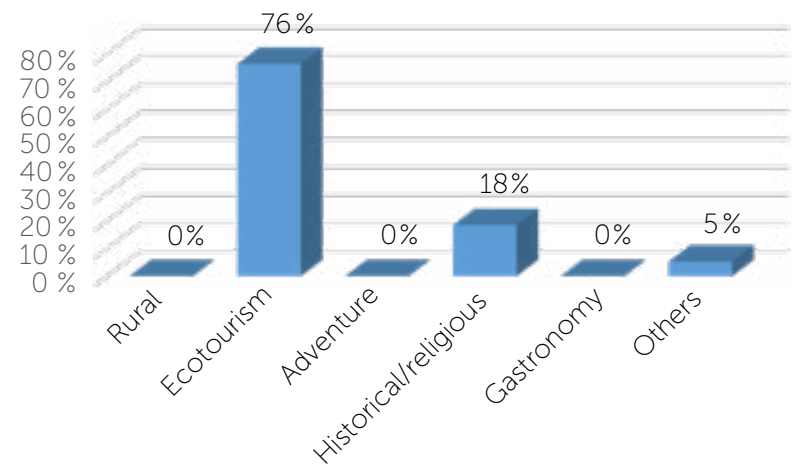

Type of management of the projects in progress

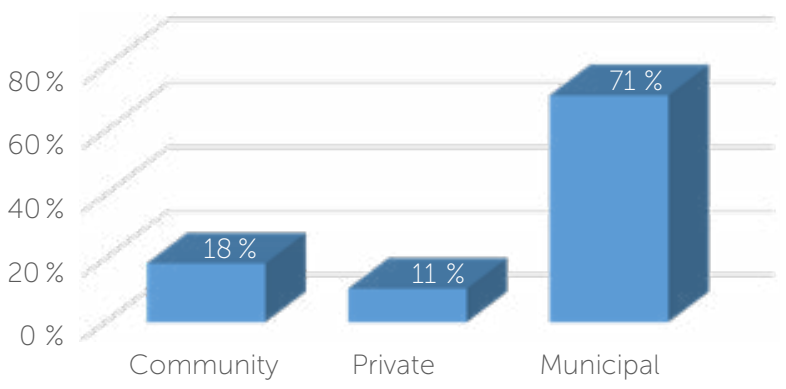

Figure 4. Percentages of management types and types of tourism in projects in process at the Altas Montañas de Veracruz region, Mexico.

\begin{tabular}{|c|c|c|c|c|c|c|c|c|c|c|}
\hline \multirow{2}{*}{ Subregion } & \multirow{2}{*}{$\begin{array}{c}\text { Projects in } \\
\text { progress }\end{array}$} & \multicolumn{3}{|c|}{ Type of management } & \multicolumn{6}{|c|}{ Type of tourism } \\
\hline & & C & $\mathrm{P}$ & M & $\mathrm{R}$ & $E$ & A & $H / R$ & $G$ & Other \\
\hline 1. Huatusco-Tlaltetela & 7 & 3 & 0 & 4 & 0 & 4 & 0 & 1 & 0 & 2 \\
\hline 2. Pico de Orizaba & 7 & 0 & 1 & 6 & 0 & 5 & 0 & 2 & 0 & 0 \\
\hline 4. Zongolica-Tezonapa & 0 & 0 & 0 & 0 & 0 & 0 & 0 & 0 & 0 & 0 \\
\hline 5. Centro-Cordoba & 17 & 4 & 3 & 10 & 0 & 13 & 0 & 4 & 0 & 0 \\
\hline Totals & 38 & 7 & 4 & 27 & 0 & 29 & 0 & 7 & 0 & 2 \\
\hline
\end{tabular}

which, according to the participants (most of them in charge of tourism in their municipalities), have potential use. In this case, the elements with touristic potential with community management stand out, followed by those of municipal management. Regard their tourism type, the ecotourism ones stand out, followed by the historical / cultural (Table 5; Figure 5).

In total, 53 problems were registered (Table 6; Figure 6). In this subject, economic problems stand out, mainly emphasizing the lack of resources for tourism and, consequently, the lack of infrastructure for it, among other relevant aspects. It is followed by technical problems, related to a lack of training of the municipalities for proper development of tourism in their territories.

The results obtained are encouraging, taking into account that, from the 57 existing municipalities in the region, 32 of them were present at the workshop (more than 56\%). Also, it is worth highlighting the interest shown by the 


\begin{tabular}{|c|c|c|c|c|c|c|c|c|c|c|}
\hline \multirow{2}{*}{ Subregion } & \multirow{2}{*}{ EP } & \multicolumn{3}{|c|}{ Type of management } & \multicolumn{6}{|c|}{ Type of tourism } \\
\hline & & C & $\mathrm{P}$ & M & $\mathrm{R}$ & $E$ & A & $H / R$ & G & Other \\
\hline 1. Huatusco-Tlaltetela & 20 & 4 & 3 & 13 & 0 & 7 & 4 & 8 & 1 & 0 \\
\hline 2. Pico de Orizaba & 31 & 16 & 2 & 13 & 0 & 16 & 0 & 12 & 2 & 1 \\
\hline 4. Zongolica-Tezonapa & 6 & 6 & 0 & 0 & 0 & 6 & 0 & 0 & 0 & 0 \\
\hline 5. Centro-Cordoba & 41 & 17 & 18 & 6 & 1 & 14 & 6 & 14 & 1 & 5 \\
\hline Totals & 130 & 54 & 28 & 48 & 1 & 57 & 12 & 46 & 5 & 9 \\
\hline
\end{tabular}

\section{Type of management Elements with Potential}

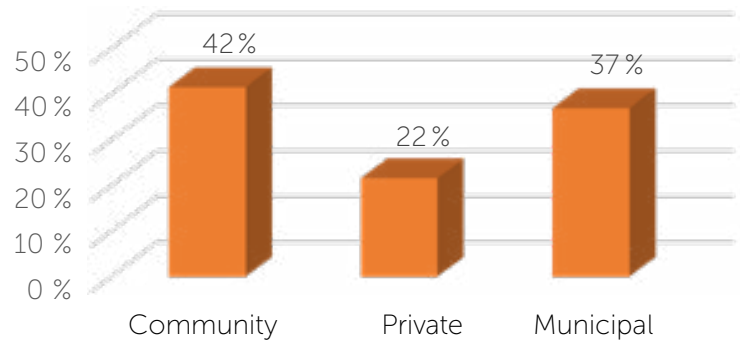

Type of Tourism of Elements with Potential

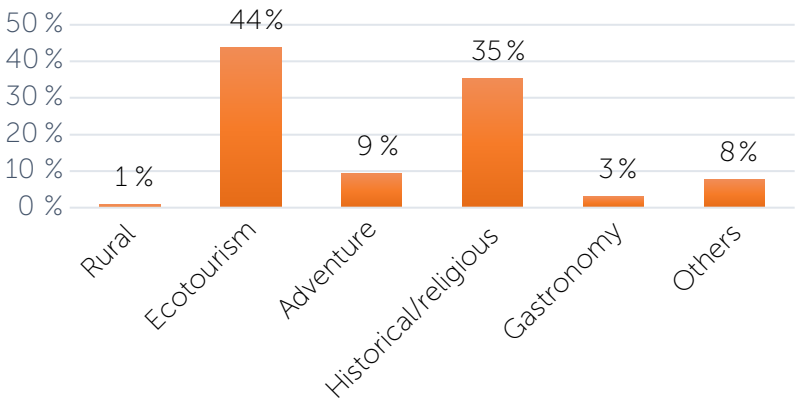

Figure 5. Percentages of management types and types of tourism of elements with touristic potential for development in the Altas Montañas de Veracruz region, Mexico.

participants, working hard with the organizing team, to combine the information presented here.

On the other hand, the number of consolidated projects, 106 for 32 participating municipalities, that is, 3.31 consolidated projects on average per municipality, is high if we consider that information was obtained from little more than half of the municipalities in the region, therefore a higher number is to be expected for the entire region. It also stands out that most of the projects are community and private, however, most of the projects in process are initiatives of current municipal authorities. These speak of the rebound and interest that municipalities are having in the tourism issue, considering that those municipalities took possession in December 2017 and the workshop was held in April 2018. The elements with identified tourist potential had a high number of records (130), which stands out if we take into account that only a little more than half of the municipalities in the region participated, so this number will likely increase for the region as a whole. It also to be noted that most

\begin{tabular}{|c|c|c|c|c|c|}
\hline Subregion & $\begin{array}{l}\stackrel{U}{+} \\
\stackrel{0}{0} \\
\frac{\varepsilon}{0} \\
00 \\
0 \\
0\end{array}$ & $\begin{array}{l}\vec{\sigma} \\
\frac{d}{d} \\
\frac{0}{0} \\
\frac{\varepsilon}{<}\end{array}$ & 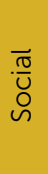 & $\begin{array}{l}\overrightarrow{\widetilde{U}} \\
\cdot \frac{\delta}{E} \\
0 \\
\tilde{0} \\
\mathcal{U}\end{array}$ & 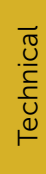 \\
\hline 1. Huatusco-Tlaltetela & 10 & 1 & 1 & 6 & 2 \\
\hline 2. Pico de Orizaba & 12 & 1 & 2 & 4 & 5 \\
\hline 3. Acultzingo-Orizaba & 15 & 5 & 3 & 5 & 2 \\
\hline 4. Zongolica-Tezonapa & 1 & 0 & 1 & 0 & 0 \\
\hline 5. Centro-Cordoba & 15 & 1 & 5 & 5 & 4 \\
\hline TOTALS & 53 & 8 & 12 & 20 & 13 \\
\hline
\end{tabular}

\section{Problems around tourism}

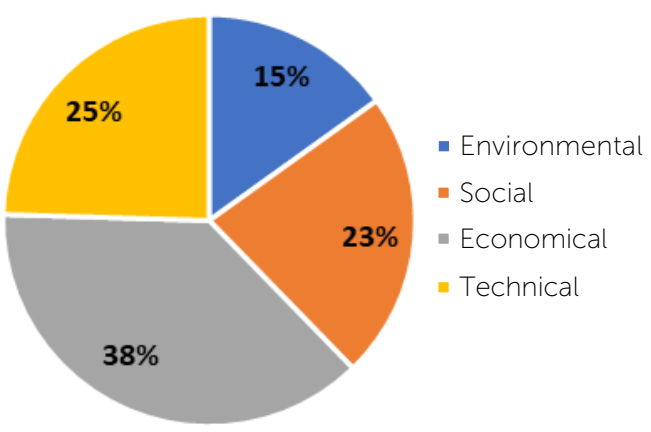

Figure 6. Percentages of problems related to tourism in the Altas Montañas de Veracruz region, Mexico. 
of the elements with touristic potential are of community or municipal management, which would facilitate their use by rural communities in the region. Finally, most of these elements are ecotourism and historical / cultural, which is consistent with the biocultural richness of the region.

At all times during the workshop process, the total willingness of the participating municipal authorities to collaborate with the Colegio de Postgraduados Córdoba Campus of the and in strengthening nature-based tourism in the region. Likewise, most participants showed interest and willingness to continue collaborative work, to develop an ecotourism network and receive training in different topics related to it, to create new projects, improve those they already have, and overall, to have a better touristic offer, integrated and shared by all or several participants of this network, in the form of different tourist routes.

\section{CONCLUSIONS}

Finally, this exercise was important to assess a considerable number of those involved in ecotourism in the region to initiate a collaborative process among all interested parties. As already mentioned, a large number of elements with touristic potential is a highlight of the region, as a consequence of the great biocultural wealth in the area. These can be used and conserved through nature-based tourism, that is, tourism can be a tool for sustainable use of biocultural richness, as well as being an excellent means of promotion and thus, valued for its proper measure.

\section{ACKNOWLEDGMENTS}

The authors thank the participation of the municipalities of the High Mountains of Veracruz, Mexico, and their time invested in the workshop is appreciated. We thank the researchers and students of the Colegio de Postgraduados Campus Córdoba for their support in organizing and carrying out the workshop

\section{REFERENCES}

Del Barco-Quiroga, L.V. (2010). Turismo comunitario en países en vías de desarrollo: Buenas prácticas para la planificación de un emprendimiento (Proyecto de investigación). Instituto Universitario de Investigaciones Turísticas, Universidad de Alicante. 13 p

García Muñoz-Aparicio, C., Pérez-Sánchez, B., \& Navarrete-Torres, M.C. (2017). La importancia del turismo religioso en México. International Journal of Scientific Management and Tourism 3(1): 131-143

INAFED (Instituto para el Federalismo y el Desarrollo Municipal). (2010). Enciclopedia de los municipios y delegaciones de México. Regionalización del estado de Veracruz de Ignacio de la Llave. Disponible en: http://www.inafed.gob.mx/ work/ enciclopedia/EMM30veracruz/regionalizacion.html. Consultado: 22/02/2019.

Kieffer, M. (2018). Conceptos claves para el estudio del Turismo Rural Comunitario. El Periplo Sustentable 34: 8-43.

López-Ojeda, A., Favila-Cisneros, H., Osorio-Manjarrez, A., HernándezLópez, R., \& Guzmán-Hernández, C. (2019). Desafíos del turismo sustentable desde la dimensión local: el caso de los municipios de Isidro Fabela y Jilotzingo, Estado de México. El Periplo Sustentable 36: 67-99. DOI: https://doi.org/10.36677/ elperiplo.v0i36.9251

OMT (Organización Mundial del Turismo). (2017). Segundo informe de la OMT sobre turismo gastronómico: sostenibilidad y gastronomía. Disponible en: https://media.unwto.org/es/ press-release/2017-05-25/segundo-informe-de-la-omt-sobreturismo-gastronomico-sostenibilidad-y-gastr. Consultado: 21/04/2019

Rivera-Hernández, J.E., Pérez-Sato, J.A., Alcántara-Salinas, G., ServínJuárez, R., \& García-García, C.G. (2018). El Ecoturismo y el Turismo Rural en la región de las Altas Montañas de Veracruz: Potencial, Retos y Realidades. Agroproductividad 11(8): 129135. Doi: https://doi.org/10.32854/agrop.v11i8.1108

SECTUR (Secretaría de Turismo). (2003). Planeación y gestión del desarrollo turístico municipal (un enfoque de cambio). Subsecretaría de Operación Turística, Dirección General de Desarrollo de Productos Turísticos. México. 185 p.

SECTUR (Secretaría de Turismo). (2004). Turismo alternativo, una nueva forma de hacer turismo. Secretaría de Turismo. México. $23 \mathrm{p}$.

SECTUR (Secretaría de Turismo). (2017). Estrategia para el Impulso y Desarrollo del Turismo de Naturaleza en México (Borrador). Dirección General de Planeación, Dirección de Política Intersectorial, Subsecretaría de Planeación y Política Turística. México. $64 \mathrm{p}$

\section{4 \\ AGRO

